\title{
Effectiveness of Planned Teaching Programme on Knowledge Regarding Effects of Anemia on Mother and Fetus Among the Pregnant Women in Selected Rural Hospitals
}

\section{Teltumbde Archana}

Department of Obstetrics \& Gynaecology Nursing, SRMM College of Nursing, Datta Meghe Institute of Medical Sciences (Deemed to be University) Sawangi (Meghe) Wardha, Maharashtra, India

\section{ABSTRACT}

Anemia is the world's most common nutritional deficiency, and it is a major contributor to pregnancy complications and outcomes.According to the WHO, anemia is a condition in which the number of circulating red blood cells. Objectives of study: 1. To assess the knowledge regarding the effects of anemia on mother and fetus among pregnant women. 2.To evaluate the efficacy of planned education on the effects of anemia on the mother and fetus in pregnant women.3.To find the association between selected demographic variables with knowledge score regarding effects of anemia on mother and fetus among pregnant women.Material and Methods: Purposive sampling was used to collect 50 samples from antenatal wards in various hospitals.A one-group pre- and post-test design with no control group was used for the research.The findings revealed that in the pretest, $10 \%$ of antenatal mothers had average knowledge, the mean percentage of knowledge score was 19.76\%, and in the posttest, 18\% of antenatal mothers had good knowledge. knowledge score was 39.76\%. Education was found to be associated with knowledge of antenatal mothers and none of the other variables were found significantly related to the knowledge of mothers.Conclusion: The main objective of the research study was to assess the efficacy of the planned teaching on awareness of the effects of anemia on the mothers and fetus in selected hospitals.

\section{KEY WORDS: ANEMIA, PREGNANT MOTHERS, FETUS, NUTRITIONAL DEFICIENCY, OXYGEN, RED BLOOD CELLS.}

\section{INTRODUCTION}

Anemia is the world's most common nutritional deficiency, and it plays a significant role in pregnancy complications and outcomes. Anemia is a condition in which the amount of circulating red blood cells reduces, lowering the ability of the mother's and foetus' vital organs to carry oxygen. Anemia is a condition that can affect both the mother and the fetus during pregnancy. Anemia during the antenatal period causes poor weight gain, PIH, placenta previa, eclamsia, abruption placenta, and premature rupture of membranes. During the intranatal period, for example, preterm labour is a maternal risk complication, intranatal hemorrhage, shock

Biosc Biotech Res Comm P-ISSN: 0974-6455 E-ISSN: 2321-4007

\section{crossef}

Identifiers and Pagination

Year: 2021 Vol: 14 No (9) Special Issue

Pages: 11-14

This is an open access article under Creative

Commons License Attribn 4.0 Intl (CC-BY).

DOI: $h t t p: / / d x$.doi.org/10.21786/bbrc/14.9.3 and anesthesia related heart failure to name a few. The postnatal period can be complicated by postnatal sepsis, sub-involution, and embolism, prematurity, low birth weight, low APGAR score, fetal distress and neonatal distress requiring prolonged resuscitation are all examples of anemia related complications.

\section{Objectives Of The Study}

- To assess the knowledge regarding the effects of anemia on mother and fetus among pregnant women

- To evaluate the efficacy of planned education on the effects of anemia on the mother and fetus in pregnant women.

- To find the association between selected demographic variables with knowledge score regarding effects of anemia and fetus among pregnant women.

\section{RESULTS}

Distribution of Pregnant Women With Regards To Demographic Variables: 22\% of the pregnant women were in the age group of 18-20 years, 30\% were in the
Article Information

Received: $11^{\text {th }}$ Apr 2021

Accepted after revision: $18^{\text {th }}$ June 2021 
age group of 21-22 years and 24\% of them were in the age group of 23-25 years and more than 25 years respectively. 50\% of the pregnant women were Hindus, 36\% of them were Christian, 10\% were Muslim and 4\% of them belonged to other religions respectively. 44\% of the pregnant women were educated up to primary standard and 56\% up to secondary standard only. 4\% of the pregnant women were government servants, 30\% were doing private service and 66\% of them were doing other professions.

\section{DISCUSSION}

The present study was conducted in a rural hospital in Maharashtra and the subject was selected through purposive sampling technique. The tool for data collection was a structural knowledge questionnaire. The pre-test was conducted on the first day, followed by a planned teaching programme and the post test was conducted on the seventh day. One of the studies was conducted in 16 Indian districts to determine the prevalence of anemia among pregnant women and teenage girls. The 30 clusters were chosen using a two- stage random sampling process. 94.9 percent of pregnant women had anaemia with $\mathrm{Hb} 11 \mathrm{~g} / \mathrm{dl}$, and 13.1 percent had extreme anaemia with $\mathrm{Hb} 7 \mathrm{~g} / \mathrm{dl}$, according to the findings. The overall prevalence of anaemia among adolescent girls was 90.1 percent, with mild, moderate, and extreme anaemia being the most common. The study findings showed that the planned teaching was highly effective in improving knowledge of mothers. There was a significant association between the level of knowledge with education and other demographic variables not found significant.

\section{Nursing Implication}

Nursing practice: The staff and student nurses can use the planned teaching to impart the knowledge of anemia to mother and fetus among pregnant women in the hospital and community. The tool prepared for this study can be used to assess the knowledge of mothers, Primigravida, multigravida working women. Staff nurses and student nurses and female health workers regarding the effects of anemia on mother and fetus among pregnant women. The staff nurses in obstetrics and gynaecology wards can use this tool for the same

\begin{tabular}{|c|c|c|c|}
\hline \multirow{2}{*}{$\begin{array}{l}\text { Level of knowledge } \\
\text { score }\end{array}$} & \multirow{2}{*}{ Percentage score } & \multicolumn{2}{|c|}{ Level of Pretest knowledge score } \\
\hline & & Frequency & Percentage \\
\hline Poor & $0-25 \%$ & 40 & 80 \\
\hline Average & $26-50 \%$ & 10 & 20 \\
\hline Good & $51-75 \%$ & 0 & 0 \\
\hline Excellent & $76-100 \%$ & 0 & 0 \\
\hline \multicolumn{2}{|c|}{ Mean \pm SD } & \multicolumn{2}{|c|}{$4.92 \pm 2.04$} \\
\hline \multicolumn{2}{|c|}{ Mean $\%$} & \multicolumn{2}{|c|}{$19.76 \pm 8.17$} \\
\hline \multicolumn{2}{|c|}{ Range } & \multicolumn{2}{|c|}{1 to 10} \\
\hline
\end{tabular}

Nursing Administration: Administrators of hospitals, primary health care centers, and sub-centres can develop a policy to educate community members about anemia during pregnancy in order to improve the health of mothers and prevent complications from anemia of the mother and fetus.Nurse administrators are the key people to plan. Organize and conduct service education programmes. Nurse administrator's support should be necessary to conduct and evaluate health education programme. They can help to improve the knowledge of the staff nurses working in the Obstetrics and Gynaecology department by providing various teaching programmes with the help of various AV aids. They are in a key position to organize, implement and evaluate educative programmes which will in turn help to improve knowledge as well as to meet the future needs and accelerate the standards of health services.

Nursing Research: The main goal of nursing research is to improve the knowledge of staff nurses through the implementation of evidence-based practice. The study provides baseline data for conducting other research studies on a large scale. The study will be a reference for research scholars. Further research work can be conducted with every medical condition to identify the most effective knowledge imparting strategies.

The above table shows the frequency and percentage wise distribution of pregnant mothers from selected rural hospitals according to pre-test level of knowledge regarding the effects of anemia on mother and fetus. The levels of knowledge were seen into 4 categories, poor, average, good and excellent. $80 \%$ of pregnant mothers had a poor level of knowledge score, and 10\% of them had an average level of knowledge score. The mean pre-test knowledge score of the pregnant mothers was $4.92 \pm 2.04$.

The above table shows the frequency and percentage wise distribution of pregnant mothers from selected rural hospitals according to post-test level of knowledge regarding the effects of anemia on mother and fetus. The levels of knowledge were seen into 4 four categories, poor, average, good and excellent 10\% of pregnant mothers had a poor level of knowledge score, $72 \%$ had an average and $18 \%$ of them had a good level of knowledge score. 
The mean Post-test knowledge score of the pregnant mothers was $9.94 \pm 2.62$.

Figure 1: Distribution of pre-test knowledge score

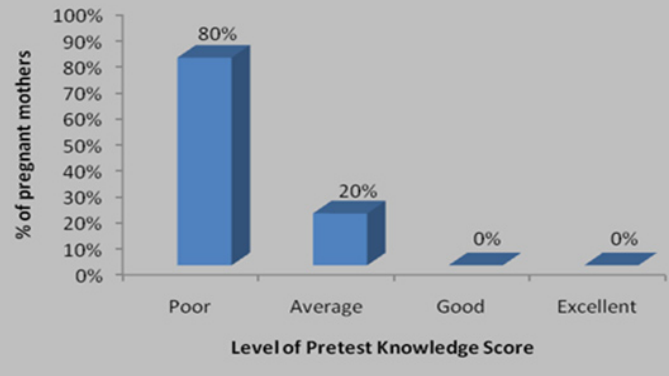

Table depicts the overall mean pre-test and post-test knowledge scores of pregnant mothers from selected rural hospitals which reveals that post-test mean knowledge score was higher 9.94 with SD of \pm 2.62 when compared with mean pre-test knowledge score which was 4.92 with SD of \pm 2.04 .

Table 2. Distribution of post-test knowledge scores for pregnant women regarding effects of anemia on mother and fetus

\begin{tabular}{l|l|l|l||}
\hline \multirow{2}{*}{$\begin{array}{l}\text { Level of knowledge } \\
\text { score }\end{array}$} & \multirow{2}{*}{ Percentage score } & \multicolumn{2}{|c|}{ Level of Post test knowledge Score } \\
\cline { 3 - 4 } & & Frequency & percentage \\
\hline poor & $0-25 \%$ & 5 & 10 \\
\hline Average & $26-50 \%$ & 36 & 72 \\
\hline Good & $51-75 \%$ & 9 & 18 \\
\hline Excellent & $76-100 \%$ & 0 & 0 \\
\hline Mean \pm SD & $9.94 \pm 2.62$ & \\
\hline Mean \% & $39.76 \pm 10.51$ \\
\hline Range & 3 to 14 \\
\hline
\end{tabular}

Figure 2: Distribution of pre-test knowledge score

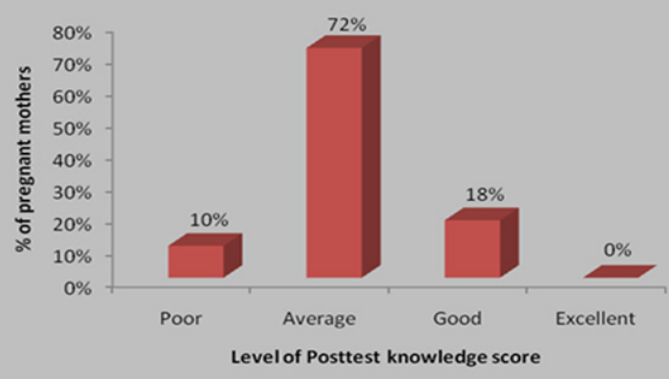

Hence it is statistically interpreted that planned teaching programme on knowledge regarding effects of anemia on mother and fetus among pregnant mothers was effective. Thus H1 is accepted and HO is rejected.

Association of knowledge score regarding effects of anemia on mother and fetus in relation to education: The association of knowledge score with educational level of pregnant mothers. The tabulated $F$ values was 2.79 ( $\mathrm{df}=3.46$ ) which is much less than the calculated ' $\mathrm{F}$ ' i.e. 12.20 at $5 \%$ level of significance also the calculated 'p'=0.0001 which was much less than the acceptable level of significance .i.e. $p=0.05$ hence it is interpreted that educational level of pregnant mothers is statistically associated with their post-test knowledge score.

Table 3. Significance of difference between knowledge scores in pre and post-test of pregnant women regarding effects of anemia on mother and fetus

\begin{tabular}{l|c|c|c|c|c|}
\hline Overall & Mean & SD & $\begin{array}{c}\text { Mean } \\
\text { difference }\end{array}$ & t- value & p- value \\
\hline Pretest & 4.92 & 2.04 & $5.02 \pm 1.72$ & 20.63 & $0.0001, S$ \\
\hline
\end{tabular}

Figure 3: Overall mean pretest and post-test knowledge scores of pregnant mothers

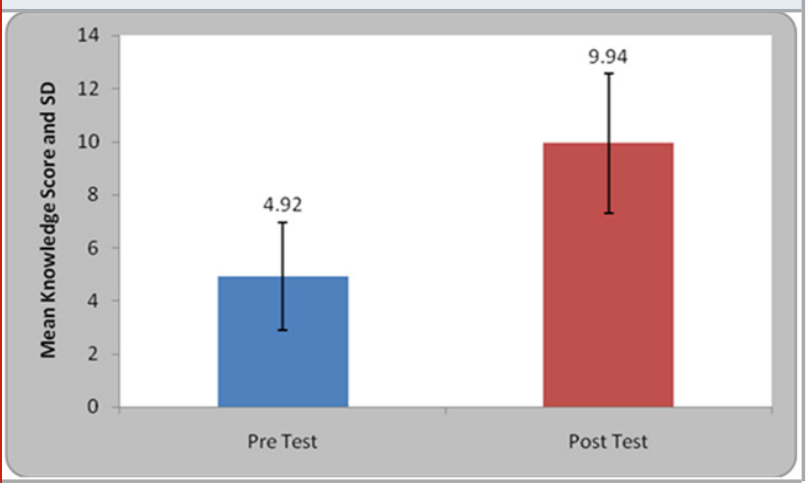

\section{Recommendations}

- A similar study can be replicated on a large scale to generalize the findings.

- A similar study can be conducted by using video assisted teaching.

- A similar study can be conducted to find out the difference in the knowledge level of the staff nurses on the basis of various institutional settings such as government and private settings.

- A similar study can be conducted to find the knowledge level of the nursing students

- A similar study can be conducted in community areas.

\section{CONCLUSION}

The teaching programme was effective as the post-test knowledge score improved than the pre-test knowledge score, so the planned teaching programme has proved to improve the knowledge of pregnant mothers to prevent anemia during pregnancy and also fetal complications.

\section{ACKNOWLEDGEMENTS}

I would like to express my sincere thanks to all faculties of Smt. Radhikabai Nursing College, Sawangi (Meghe) Wardha, India for smooth completion of my research work. We acknowledge the immense help received from 
the scholars who are cited and included in references of this manuscript. We would like to thank the authors whose works have been cited and included in this study, such as Mayel EM, Tegman A Garn SM, Ridella SA Ezzati $\mathrm{M}$, Lupus $\mathrm{AD}$, Dogers A et al. We are also grateful to the authors/editors/publishers of all those articles, journals and books from where the literature for this article has been reviewed and discussed.

Conflicts of interest: Nil

Authors' Contribution: Archana Teltumbde

Source of Funding: Self

Ethical Clearance Letter No: Ref.No.DMIMS (DU)/ IEC/2017-18/6468

\section{REFERENCES}

Ezzati M, Lopez AD, Rodgers A, Vander Hoorn S, Murray CJ, (2002) Comparative Risk Assessment Collaborating
Group. Selected major risk factors and global and regional burden of disease. The Lancet. Nov 2; 360 (9343) :1347-60.

Gautam VP, Bansal Y, Taneja OK, Saha R. (2002) Prevalence of anaemia amongst pregnant women and its socio-demographic associates in a rural area of Delhi. Indian JCommunity Med. Oct 1; 27 (4) :157.

Garn SM, Ridella SA, Petzold AS, Falkner F. (1981) Maternal hematologic levels and pregnancy outcome. Semin perinatol.; 5(1) :115-62.

Marahatta R. (2007) Study of anaemia in pregnancy and its outcome at Nepal Medical College Teaching Hospital, Kathmandu, Nepal. Nepal Medical College journal: NMCJ. Dec 1; 9 (4) :270-4.

Rajole KM, Rajole MP. (2019) Prevalence of Anaemia during Pregnancy in Nashik District, India. Int J Intg Med Sci.; 6 (1) :769-3. Dutta DC. Textbook of obstetrics. 7th ed. Howrah: New central agency (P) ltd; 2011.p.26075. 